\title{
SISTEM PENDUKUNG KEPUTUSAN PENERIMAAN DAN PENILAIAN KARYAWAN WAREHOUSE DENGAN APLIKASI WEB
}

\author{
Irfan Agus $\mathrm{M}^{1}$, Fitri Marisa, ${ }^{2}$, Indra Dharma Wijaya ${ }^{3}$ \\ fitrimarisa@widyagama.ac.id,indra.dharma@gmail.com
}

\begin{abstract}
Decision support system is a alternative in taking decisions that are quite effective. The problem in this research is how to build a system of recruitment and employee assessment warehouse that is superior by using Simple Additive weighting method (SAW). SAW method is a step that could help in the recruitment and assessment took this decision in the warehouse employees of PT. Alfaria Trijaya Resources Tbk branch Malang. And the goal of this experiment is to implement a decision support system for selecting and assessing the warehouse employees using SAW method so it can be more selective in choosing and assessing employees. The results from the sum of the highest grade in the state will be accepted.
\end{abstract}

Intisari- Sistem pendukung keputusan merupankan sutau alternative dalam mengambil keputusan yang cukup efektif. Permasalahan pada penelitian ini adalah bagaimana membangun Sistem perekrutan dan penilaian karyawan warehouse yang lebih unggul dengan menggunakan metode Simple Additive Weighting (SAW). Metode SAW merupakan suatu langkah yang dapat membantu dalam menggambil keputusan perekrutan dan penilaian karyawan warehouse di PT. Sumber Alfaria Trijaya Tbk Cabang Malang. Lalu tujuannya dari penelitin ini adalah menerapkan sistem pendukung keputusan untuk memilih dan menilai karyawan warehouse menggunakan metode SAW sehingga dapat lebih selektif dalam memilih dan menilai karyawan. Hasil dari penjumlahan nilai tertinggi akan di nyatakan diterima.

Kata Kunci-Sistem Pendukung Keputusan, Penilaian Karyawan, SAW

\section{PEndahuluan}

\section{A. Latar Belakang}

Sumber daya manusia (SDM) merupakan aset potensial bagi setiap instasi, baik instasi pemeritahan maupun non pemerintahan. SDM yang berkualitas akan memudahkan suatu instansi untuk mengelola aktivitasnya, sehingga tujuan yang telah ditetapkan oleh instasi atau perusahaan dapat tercapai. Karyawan dari tingkat bawah sampai tingkat atas, harus mampu menjalankan tugasnya masing - masing sesuai dengan tanggungjawab yang telah diberikan.

Untuk menetukan perukrutan dan penilaian pegawai di butuhkan prosedur yang tersetruktur dan sistematis yang dapat di pertanggungjawabkan, yaitu melalui seleksi. Seleksi merupakan tahapan untuk mengambil keputusan, apakah calon karayawan tersebut layak di terima, maupun karyawan yang ada di instansi atau perusahaan tersebut layak mendapat penilaian yang baik. Keputusan yang di ambil ini, diharapkan tidak subyektif agar SDM yang diperoleh sesuai denagn harapan, sehingga tidak ada pihak yang dirugikan.

Untuk menghindari subyektifitas keputusan yang dihasilkan, di perluakan suatu sistem penujang keputusan (SPK) yang dapat membantu pihak managemen dalam memutuskan karyawan mana yang sesuai dengan kualifikasi sesuai dengan kebutuhan perusahaan. Kriteria yang digunakan pada sistem pendukung keputusan perekrutan karyawan, metode ini dipilih karena dapat menentukan nilai bobot untuk setiap atribut, kemudian dilanjutkan dengan proses perangkingan yang akan menyeleksi alternatif terbaik dari sejumlah alternatif. ( Eltri Jayanti : 2015).

Di sini penulis mencoba penelitian dengan menggunakan metode yang berbeda yaitu dengan menggunakan metode SAW (Simple Additive Weighting). Konsep dasar metode simple additive weighting(SAW) adalah mencari penjumlahan terbobot dari rating kinerja pada setiap alternatif pada semua atribut. Metode simple additive weighting(SAW) membutuhkan proses normalisasi matriks keputusan. (Oktovantua tp Butar : 2015)

${ }^{1}$ Mahasiswa, Universitas Widyagama Malang, Jln. Borobudur 35, Malang 65128 (tlp: 0341-492282; fax: 0341-496919)

${ }^{2,3}$ Dosen,Jurusan Teknik Informatika Universitas Widyagama Malang, Jl. Borobudur 35, Malang 65128 (tlp: 0341-492282; fax: 0341-496919; e-mail: fitrimarisa@widyagama.ac.id)

\section{LANDASAN TEORI}

\section{A. Sistem Pendukung Keputusan}

Sistem pendukung keputusan (SPK) adalah bagian dari sistem informasi berbasis komputer termasuk sistem berbasis pengetahuan atau manajemen pengetahuan yang dipakai untuk mendukung pengambilan keputusan dalam suatu organisasi atau perusahaan. Dapat juga dikatakan sebagai sistem komputer yang mengolah data menjadi informasi untuk mengambil keputusan dari masalah semi terstruktur yang spesifik.

Dari pengertian SPK maka dapat ditentukan karakteristik antara lain ( Edi Fizal ; 2012 ):

1. Sistem pendukung keputusan dirancang untuk membantu pengambilan keputusan dalam memecahkan masalah yang sifatnya semi terstruktur atau pun tidak terstruktur. 
2. Dalam proses pengolahannya sistem pendukung keputusan mengkombinasikan Penggunaan model model atau teknik- teknik analisis dengan teknik pemasukan data konvensional serta fungsi - fungsi pencari/ interogasi informasi.

3. Sistem pendukung keputusan dirancang sedemikian rupa, sehingga dapat digunakan/dioperasikan dengan mudah oleh orang - orang yang tidak mempunyai dasar kemampuan pengoperasian komputer yang tinggi. Oleh karena itu pendekatan yang digunakan biasanya model interaktif.

4. Sistem pendukung keputusan dirancang dengan menekankan pada aspek fleksibilitas serta kemampuan adaptasi yang tinggi. Sehingga mudah disesuaikan dengan berbagai perubahan lingkungan yang terjadi dan kebutuhan pemakai.

\section{B. Metode Simple Additive Weighting (SAW)}

Metode SAW sering juga dikenal istilah metode penjumlahan terbobot. Konsep dasar metode SAW adalah mencari penjumlahan terbobot dari rating kinerja pada setiap alternatif pada semua atribut. Metode SAW membutuhkan proses normalisasi matriks keputusan (X) ke suatu skala yang dapat diperbandingkan dengan semua rating alternatif yang ada

$$
r_{i j}=\left\{\begin{array}{cc}
\frac{x_{i j}}{M a x_{i j} X_{i j}} & \begin{array}{r}
\text { Jika j adalah atribut } \\
\text { keuntungan (benefit) }
\end{array} \\
\frac{M i n i x_{i j}}{X_{i j}} & \text { Jika j adalah atribut biaya } \\
(\text { cost })
\end{array}\right.
$$

Di mana:

$r_{i j} \quad=$ rating kinerja ternormalisasi.

$\max _{i}=$ nilai maksimum dari setiap baris dan kolom.

$\min _{i}=$ nilai minimum dari setiap baris dan kolom.

$X_{i j} \quad=$ baris dan kolom dari matriks.

\section{Pengertian Web}

Pengertian website adalah sering juga disebut Web, dapat diartikan suatu kumpulan-kumpulan halaman yang menampilkan berbagai macam informasi teks, data, gambar diam ataupun bergerak, data animasi, suara, video maupun gabungan dari semuanya, baik itu yang bersifat statis maupun yang dinamis, yang dimana membentuk satu rangkaian bangunan yang saling berkaitan dimana masing-masing dihubungkan dengan jaringan halaman atau hyperlink. sebagai kriteria dalam pembentukan pohon. Misalkan untuk menentukan main tenis, kriteria yang diperhatikan adalah cuaca, angin, dan suhu. Salah satu atribut merupakan atribut yang menyatakan data solusi per item data yang disebut atribut hasil.[3](Acmad \& Slamat, 2012).

\section{Pengertian Website}

Pengertian Browser,- Browser atau Penjelajah Web sudah tidak asing lagi ditelinga kita, setiap hari kita selalu berhubungan dengan browser. Aktifitas kerja ataupun hiburan kini kebanyakan dijalankan di browser dengan memanfaatkan jaringan internet. Secara singkat browser adalah alat untuk menjelajahi atau membuka konten-konten yang bertebaran di dunia maya.

Pengertian Browser adalah suatu aplikasi atau program yang dijalankan pada perangkat komputer untuk melihat konten yang ada pada media World Wide Web (WWW) dengan memanfaatkan jaringan internet. Teknologi browser yang berkembang saat ini tidak hanya dapat menampilkan halaman yang berisi text atau tulisan saja, browser-browser populer sekarang dapat menampilkan gambar, musik, suara, video, file pdf dan data lainnya.

\section{E. Penelitian Sebelumnya Sebagai Pembanding}

Dalam penelitian ini, penyusun skripsi mengkaji beberapa penelitian, antara lain :

1. Sistem Pendukung Keputusan Pemilihan Guru Berprestasi dengan Simple Additive Weighting ( Isnaini Nur Hanifah : 2014 ).

Pada penelitian ini menghasilkan suatu perancangan SPK metode SAW pemilihan guru berprestasi dengan menggunakan beberapa kriteria, antara lain : Kesetiaan ,Profesi kerja, Tanggungjawab ,Ketaatan, Kejujuran, Kerja Sama Prakasa yang diharapkan dapat dimanfaatkan untuk pemilihan guru berprestasi dan guru teladan.

2. Sistem Penilaian Kinerja Kepala Sekolah Dan Guru Pada Yayasan Kusuma Harapan Bangsa ( Eka Putra,2016 ).

Pada penelitian ini menghasilkan suatu perancangan SPK metode SAW pemberian biasiswa dengan menggunakan beberapa kriteria, antara lain : nilai study, kemapuan ekonomi dan tempat tingggal sebagai riteri - riteria yang digunakan dalam memilih mahasiswa yang laya mendapatkan biasiswa.

3. Pembangunan Sistem pendukung Keputusan Rekutmen pegawai baru di PT. ABC ( Astri. H, Utami Dwi. W : 2013 ).

Pada penelitian ini menghasilkan suatu perancangan SPK metode SAW rekrutmen pegawai di PT. ABC. Dengan menggunakan metode SAW di dapatkan jumlah nilai calon karyawan terbaik.

4. SPK Penetuan Resep Masakan berdasarkan Ketersediaan Bahan Makanan Menggunakan Metode SAW Berbasis Web ( Salsabella :2014 ).

pada penelitian ini di hasilkan perancangan SPK dalam menentukan resep masakan dengan memperhitungkan bahan makanan yang ada.

\section{ANALISIS PERANCANGAN}

\section{A. Analisis Masalah}

Dalam menentukan kelayakan sistem penerimaan barang di PT. SAT Malang. Ada beberapa factor yang dapat 
mempengaruhi penerimaan dan penilaian tersebut. Banyak proses yang saat ini masih dilakukan ssecara manual, seperti pendaftaran yang ahrus dilakukan calon karyawan.

Berikut ini beberapa tahapan yang masih dilakukan dalam penerimaan dan penilaian karyawan warehouse di PT SAT Malang.

1. Pendaftaran masih dilakukan dengan entry manual .

2. Proses peneriman masih manual.

3. Proses penilaian masih dilakukan dengan manual. dengan masih menggunaan lembar penilaian

\section{B. Flowchart Program Aplikasi}

Berikut penjelasan dari tiap proses sistem penerimaaan dan penilaian Karyawan Warehouse

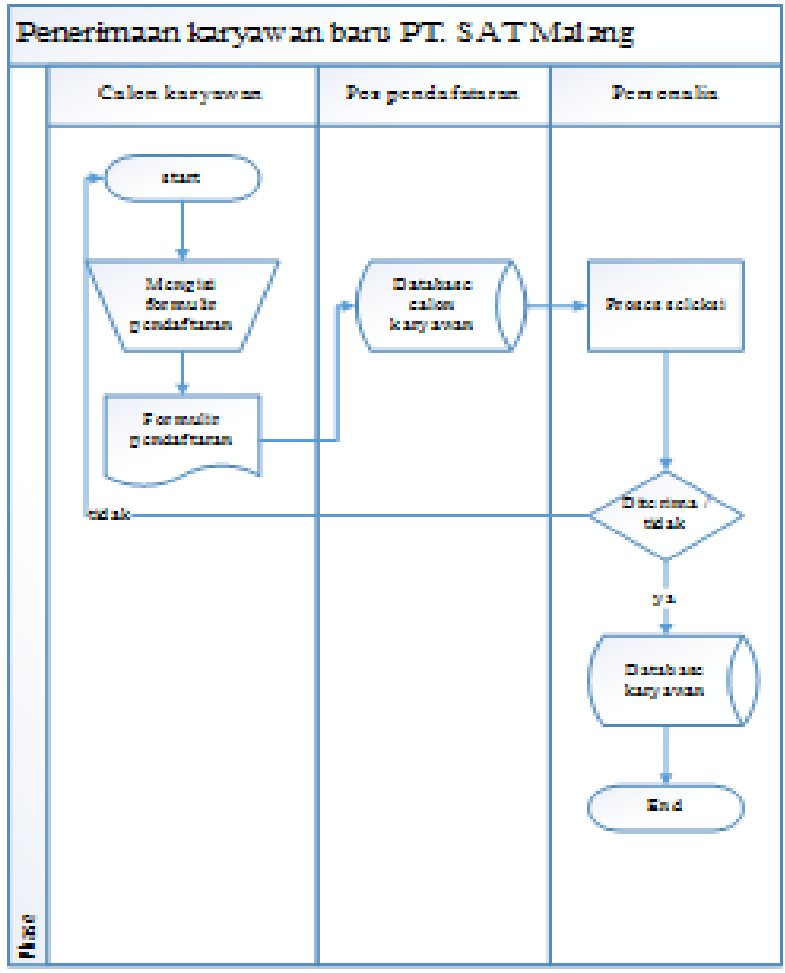

Gbr.1. Flowchart Aplikasi Penerimaan

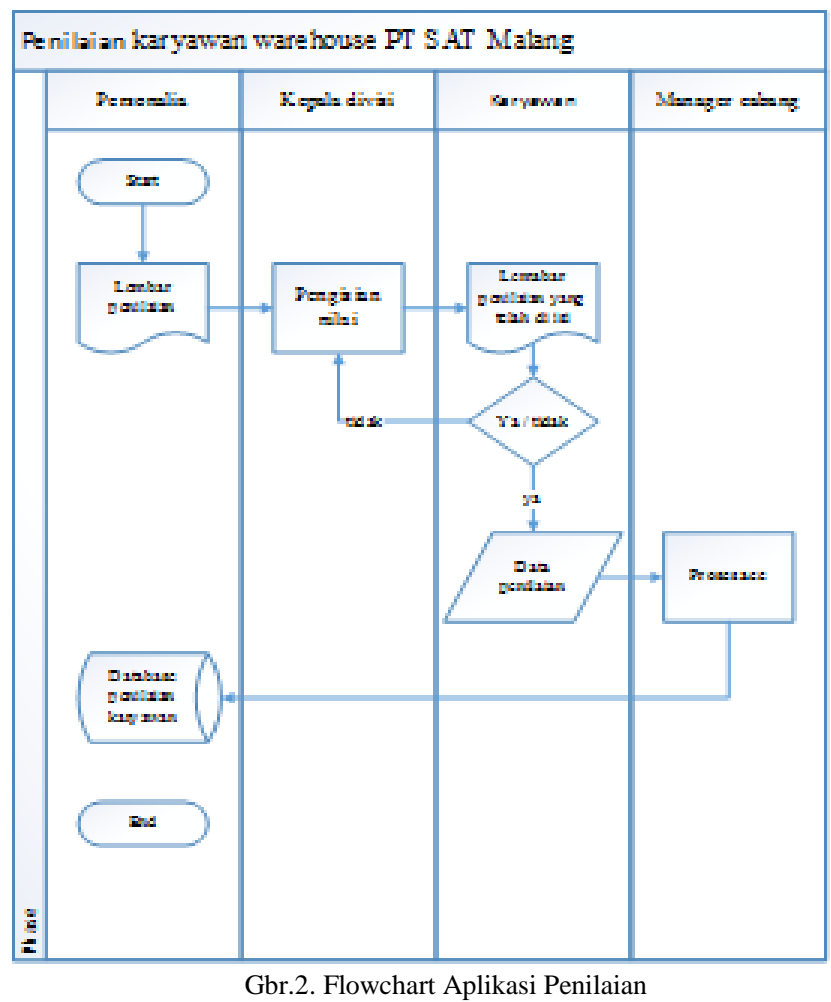

C. Perancangan Sistem

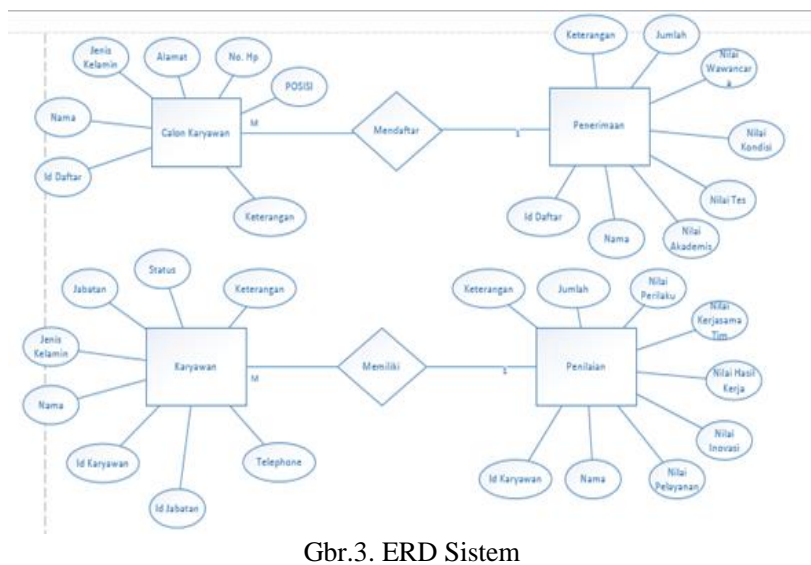

IV IMPLEMENTASI SISTEM

\section{A. Antar Muka Sistem}

Dalam mengimplementasi sistem kali ini, user terlebih dahulu harus melakukan login, login tersebut bertujuan agar user bisa mengoperasikan sistem. Jika user telah melakukan login, maka akan muncul gambar seperti di bawah ini: 


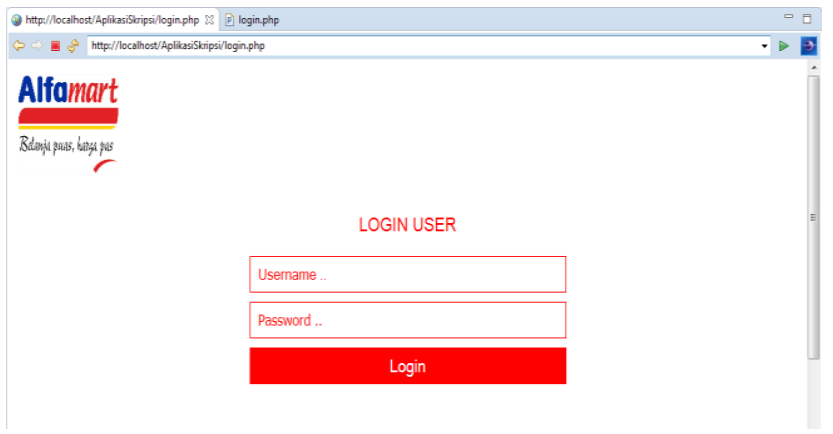

Gbr.4. Form Login

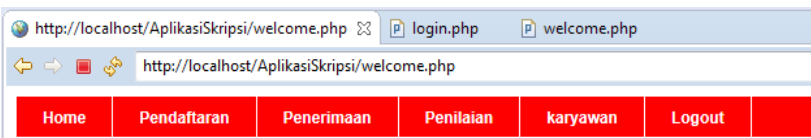

Gbr.5. Form Halaman Utama

Menu pendaftaran berisi form pendaftaran dan tampil pendaftaran. Form pendaftaran befungsi untuk menginput data - data calon karyawan. Seperti nama, jenis kelamin, tanggal lahir, alamat dan lain - lain.

Berikut tampilan form pendaftaran:

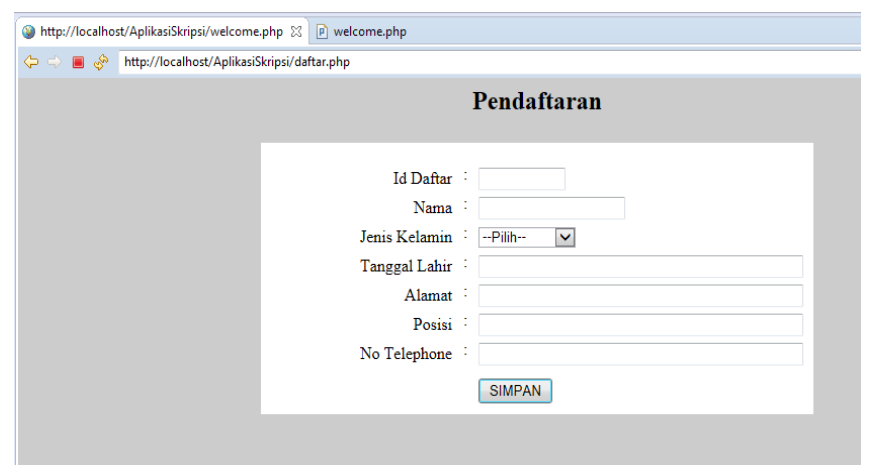

Gbr.6. Calon Pendaftaran

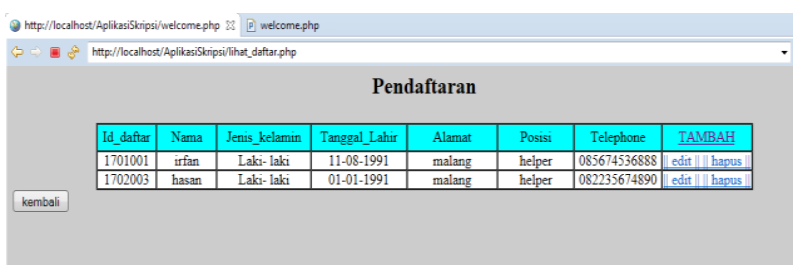

Gbr.7. Form Tampil Pendaftaran

Menu penerimaan berisi form penerimaan, form lihat penerimaan, form nilai terbaik, form cari penerimaan dan form cetak penerimaan. Form penerimaan yaitu form yang berisi bagaimana nntinya seorang calon karyawan akan di seleksi berdasarkan nilai - nilai dari hasil proses penerimaaan yaitu nilai akademis, nilai tes, nilai kondisi fisik ,dan yang terakhir nilai wawancara. Berikut tampilan form penerimaan;

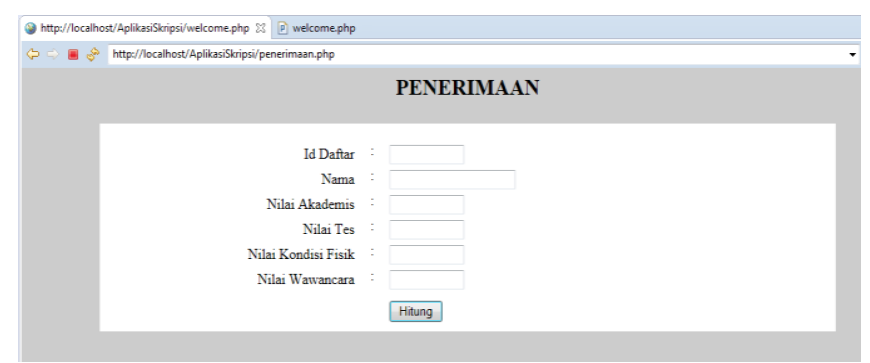

Gbr.8. Form Input Penerimaan

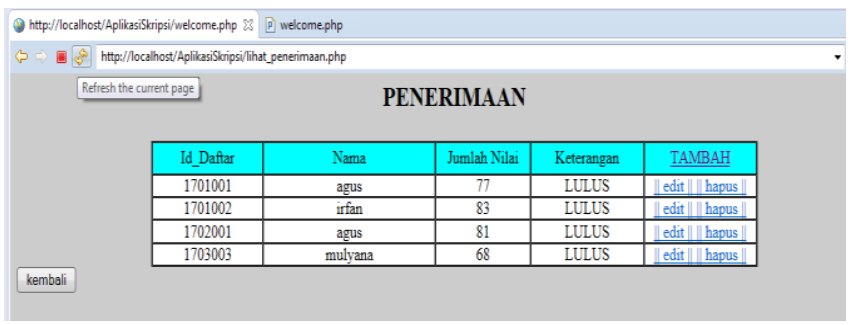

Gbr.9. Form Tampil Penerimaan

Menu karyawan berisi form input karyawan, form tampil karyawan, dan Form cetak karyawan. Form karyawan di isi darihasil penerimaan karyawan yang lulus dengan nilai baik untuk selanjutnya di masukan dalam database karyawan warehouse. Berikut tampilan input karyawan;

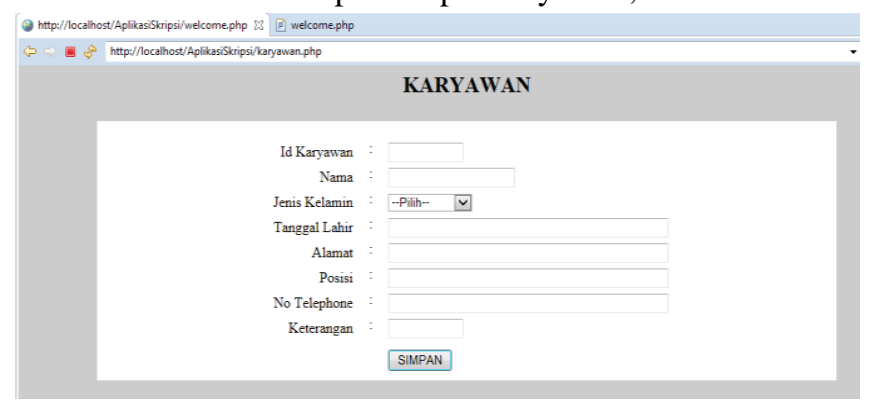

Gbr.10. Form Input Karyawan

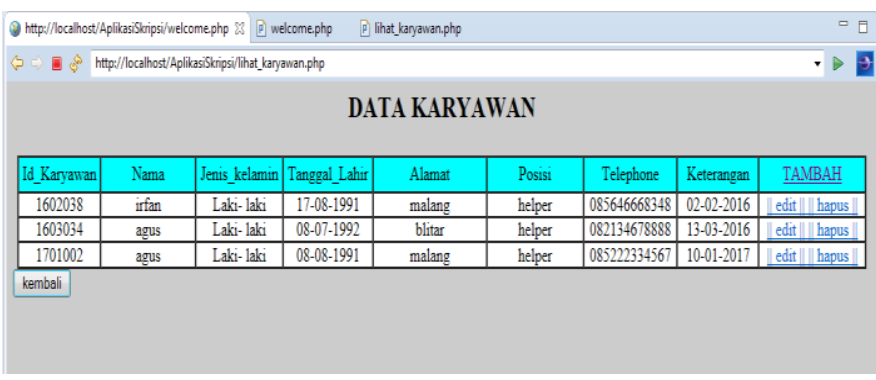

Gbr.11. Form tampil Karyawan

Dalam menu penilaian ini berisi form - form penilaian yaitu form penilaian, form lihat penilaian, form nilai terbaik, form cari penilaian dan form cetak penilaian. Form penilaian di dapatkan dari nilai- nilai yanag di berikan oleh kepala divisi serta telah di disetujui oleh maneger cabang dan di input oleh personalia. Nilai - nilai dari penilaian di bedakan berdasarkan 5 kriteria yaitu nilai pelayanan, nilai inovasi, nilai hasil kerja, nilai kerjasa tim, dan nilai perilaku. Berikut tampilan form penilaian karyawan; 


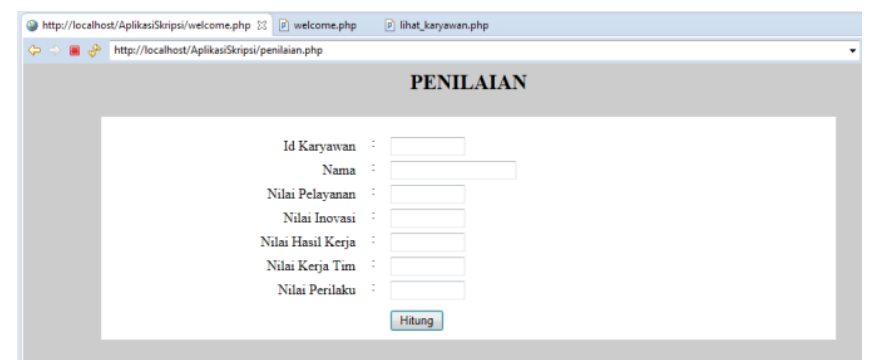

Gbr.12. Form Input Penilaian

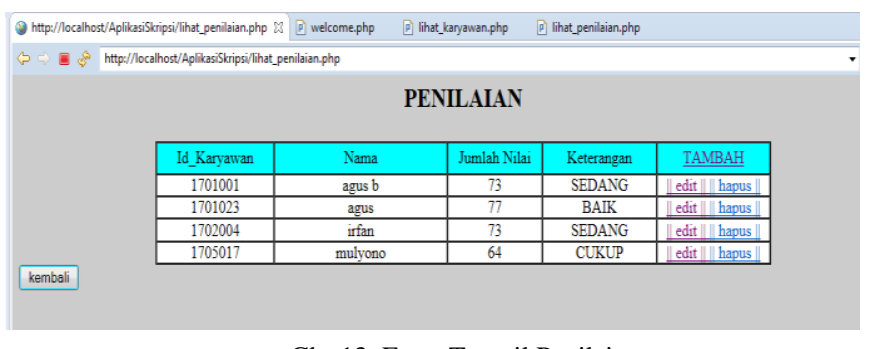

Gbr.13. Form Tampil Penilaian

\section{B. Pengujian}

Data - data nilai yang di ambil dari proses penerimaan di jumlahkan dengan bobot kriteria yang telah di tetapkan sebelumnya. Sesuai dengan metode yang digunakan yaiuti metode SAW.

Berikut bobot kriteria;

1. Nilai akademis bebobot $30 \%$

2. Nilai tes berbobot $30 \%$

3. Nilai kondisi fisik $20 \%$

4. Niali wawancara $20 \%$

\$jumlah $=(30 / 100 * \$$ nilai_akademis $)+(30 / 100 * \$$ nilai_tes $)+(20 /$ $100 *$ \$nilai_kondisi $)+(20 / 100 * \$$ nilai_wawancara $)$

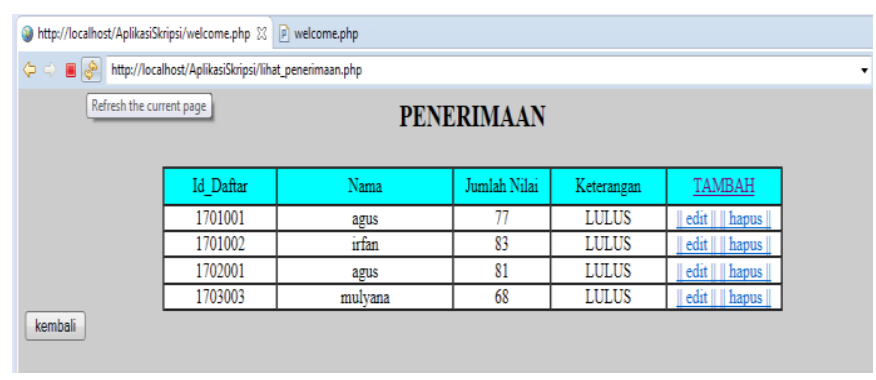

Gbr.14. Form Tampil Penenerimaan

Nilai terbsar di dapatkan oleh irfan

Sama dengan metode penerimaan, kriteria - kriteria yangberbobot di peroleh dari proses penilaian yaitu :

1. Nilai pelayan berbobot $15 \%$

2. Nilai inovasi berbobot $15 \%$

3. Nilai hasil kerja berbobot $20 \%$

4. Nilai kerja sama tim berbobot $25 \%$

5. Nilai perilaku berbobot $25 \%$

$\$$ jumlah $=(15 / 100 * \$$ nilai_pelayanan $)+(15 / 100 * \$$ nilai_inovasi $)$ $+(20 / 100 *$ \$nilai_hasil $)+(25 / 100 * \$$ nilai_tim $)+(25 / 100 * \$$ nilai_ perilaku)

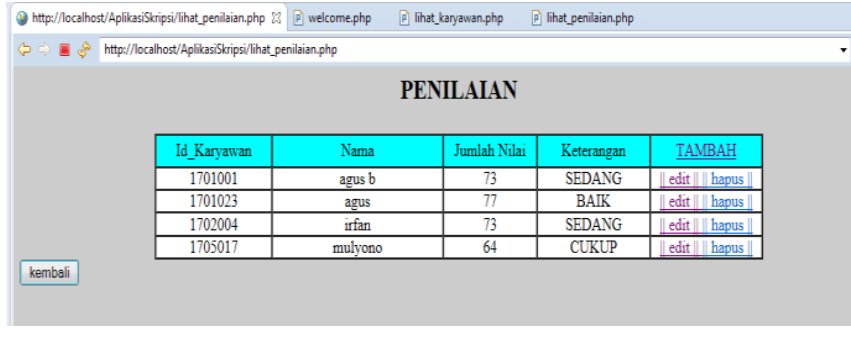

Gbr.15. Form Tampil Penilaian

Nilai terbesar di dapatkan oleh Agus

\section{KESIMPULAN}

Dari uraian yang telah dibahas, maka dapat diambil kesimpulan yaitu :

1. Dapat memilh calon karyawan warehouse sesuai dengan kriteria- kriteria yang di inginkan.

2. Memberikan apresiasi dengan bentuk penilian kepada karyawan warehouse.

3. Dan membantu perusahaan dalam mengembangkan prusahaan dengan adanya system penerimaan dan penilaian karyawan warehouse.

\section{UCAPAN TERIMA KASIH}

Terima kasih kami sampaikan kepada pihak Universitas Widyagama Malang yang telah memberikan fasilitas dan dukungan kepada kami di saat melakukan penelitian ini.

\section{REFERENSI}

1. Astri, H, dan Utami Dwi, W. Pembangunan system pendukung keputusan rekutmen pegawai baru di PT. ABC. Http://komputa.if.unikom.ac.id/_s/data/jurnal/vol.2no.2/2.2.10.2013-49-56-2089-9033.pdf/ori/2.2.10.201349-56-2089-9033.pdf

2. Edi, F. 2012. Model Aanalisis Kelayakan Lokasi Minimarket Dengan Metode Analitycal Hierarchy Proses . $\mathrm{Http} / /$ :

http://jurnal.stmikelrahma.ac.id/assets/file/Edi\%20Faizal7-stmikelrahma.pdf.

3. Eka, P. 2016. Sistem Penilaian Kinerja Kepala Sekolah Dan Guru Pada Yayasan Kusuma Harapan Bangsa. Https://jurnal.pcr.ac.id/index.php/jakt/article/view/702

4. Elrti, J. 2015. Penerapan Metode SAW Dalam Sistem Pendukung Keputusan Perkrutan Karyawan ( Studi Kasus : PT. Perkebunan Nusantara III Medan). Http://www.ilmuskripsi.com/2016/05/jurnal-penerapanmetode-simple-additive.html

5. Isnaini Nur, H. 2014. Sistem Pendukung Keputusan Pemilihan Guru Berprestasi dengan Simple Additive Weighting.

Http://journal.unnes.ac.id/nju/index.php/jte/article/view/35 75

6. Oktovantua, B. 2015. Sistem Pendukung Keputusan Rekomendasi Penerimaan Bantuan Siswa Miskin Dengan Metode SAW. Http://www.ilmuskripsi.com/2016/05/jurnalsistem-pendukung-keputusan 84.html.

7. Salsabella. 2014. SPK penetuan resp masakan berdasarkan ketersediaan bahan makanan menggunakan metode SAW berbasis Web. 